ISSN : $2302-1590$

E-ISSN: $2460-190 \mathrm{X}$

ECONOMICA

Journal of Economic and Economic Education Vol.1 No.1 (16-31)

\title{
MODEL SISTEM PEMBAYARAN JASA LINGKUNGAN DALAM KAITANNYA DENGAN KONSERVASI SUMBERDAYA AIR DAN LAHAN: STUDI KASUS PADA BATANG ANAI SUMATERA BARAT
}

\author{
Dasrizal, Ansofino, Erna Juita, Jolianis \\ Dosen STKIP PGRI Sumbar \\ Jl. Gunung Pangilun No.1, Padang Sumatera Barat \\ Email: ansofino2001@yahoo.com
}

\author{
Submitted: 2012.09.10 Reviewed: 2012.09.22 Accepted: 2012.10.18 \\ http://dx.doi.org/10.22202/economica.2012.v1.i1.102
}

\begin{abstract}
This study found that 1) West Sumatra has the potential water resources are more than sufficient to meet the need for the use of water for irrigation, drinking water and for industrial use and use for power generation. 2) In the Batang Anai watershed areas, water resource use is dominated by irrigation water users, especially in Pariaman District, while the use of the water is not there. 3) water in Batang Anai River Basin has not been streamed to users who value efficient that water usage not in accordance with the principle of efficiency. 4) The total area of watershed Batang Anai has decreased from year to year, which affects the availability of water is declining. 5) The competent authorities in managing the watershed Batang Anai is PSDA West Sumatra province of Sumatra and Central River Region V and Watershed Management Board AgamKuantan. 6) In making the benefits of water resources in the watershed currently Batang Anai, industrial users are not there, which is the dominant irrigation and household water users. 7) Number of total water use of population catchment area totaling 6,439,233 Batang Anai is 6,439,233 m3/tahun/person, this only amounted to $5.04 \%$ of the existing availability of water in the watershed Batang Anai that amounted in 2011 was 127, 38 million m3/year. Batang Anai River Basin water users the greatest population in the district was 1,332,183 m3/year Means Batang Anai River Basin water use for household purposes is still quite small. 8) Use Batang Anai River Basin water for irrigation purposes with irrigated area reached 13,604 ha, with the need for the flow of water is equal to $10.15 \mathrm{m3}$, the water requirements for wetland that will be irrigated by water is much Batang Anai $16324.8 \mathrm{~m} 3 / \mathrm{ha}$.

Abstrak

Studi ini menemukan bahwa 1) Sumatera Barat memiliki potensi sumber daya air yang lebih dari cukup untuk memenuhi kebutuhan penggunaan air untuk irigasi, air minum dan untuk keperluan industri dan digunakan untuk pembangkit listrik. 2) Di daerah Batang Anai DAS, penggunaan sumber daya air didominasi oleh pengguna air irigasi, terutama di Pariaman, sedangkan penggunaan air tidak ada. 3) air di Batang Anai River Basin belum dialirkan ke pengguna yang menghargai efisien bahwa penggunaan air tidak sesuai dengan prinsip efisiensi. 4) Luas total DAS Batang Anai mengalami penurunan dari tahun ke tahun, yang mempengaruhi ketersediaan air menurun. 5) Pihak yang berwenang dalam pengelolaan DAS Batang Anai adalah provinsi PSDA Sumatera Barat Sumatera dan Balai Besar Wilayah Sungai V dan Manajemen Daerah Aliran Sungai Dewan Agam-Kuantan. 6) Dalam membuat manfaat sumber daya air di DAS saat ini Batang Anai, pengguna industri tidak ada, yang merupakan pengguna irigasi dan air rumah tangga dominan. 7) Jumlah total penggunaan air dari daerah tangkapan penduduk sebesar 6.439.233 Batang Anai adalah 6.439.233 m3 / tahun / orang, ini hanya sebesar 5,04\% dari ketersediaan air yang ada di DAS Batang Anai yang sebesar tahun 2011 127, 38 juta m3 /tahun. pengguna air Batang Anai River Basin populasi terbesar di kabupaten itu 1.332.183 m3 / tahun penggunaan air Sarana Batang Anai River Basin untuk keperluan rumah tangga masih cukup kecil. 8) Gunakan Batang Anai River Basin air untuk keperluan irigasi dengan daerah irigasi mencapai 13.604 ha, dengan kebutuhan untuk aliran air sama dengan 10,15 m3, kebutuhan air untuk lahan basah yang akan diairi oleh air jauh Batang Anai 16.324,8 m3 / Ha.
\end{abstract}

Keywords: Environmental services payment, water conservation, land conservation, Batang Anai, West Sumatra 


\section{PENDAHULUAN}

Sumberdaya air merupakan sumberdaya alam yang paling essential bagi setiap jenis kehidupan. Sementara supply air menjadi semakin langka, karena terjadi degradasi lingkungan. Sedangkan persediaan air yang mencukupi merupakan prasyarat bagi pembangunan manusia dan ekonomi. Telah diakui bahwa perilaku manusia (human behavior) dapat memiliki pengaruh besar atas ketersediaan sumberdaya air di DAS lokal dan ekosistem global. Oleh karenanya diperlukan adanya sistem insentif bagi pengaturan perilaku tersebut dalam rangka untuk stabilisasi dan keberlanjutan kehidupan manusia di masa depan. Sistem insentif yang dimaksud untuk menghemat air berupa harga air yang tepat (the right price) dan didukung oleh sistem kelembagaan yang benar (the right institution). Peningkatan jumlah penduduk dan pendapatan masyarakat telah mengakibatkan peningkatan terhadap permintaan (demand) terhadap air bersih, apabila standard kehidupan masyarakat menjadi meningkat, terutama di perkotaan. Sehingga konsumsi air perkapita juga akan menjadi meningkat. Keadaan ini menunjukkan bahwa tingkat ketersediaan air sudah berkaitan dengan kemajuan ekonomi.

Ketersediaan Sumberdaya Air di wilayah Hilir tergantung kepada upaya konservasi lingkungan (Lahan Hutan di daerah aliran sungai (DAS) sebelah Hulu). Sedangkan upaya konservasi tergantung kepada Sistem Insentif berupa Pembayaran untuk Jasa Lingkungan (PJL). Sistem ini sebaiknya dapat dibuat seflexible mungkin agar dapat disesuaikan kepada kondisi-kondisi yang berbeda-beda. Skema ini terdiri dari pembayaran atau kompensasi langsung oleh para pengguna dari jasa-jasa di Hilir kepada para penyedianya di Hulu. Skema PJL ini diharapkan dapat dilaksanakan secara langsung dan akan menjanjikan mekanisme kompensasi dimana para
Dasrizal, Ansofino, Erna Juita, Jolianis penyedia jasa-jasa lingkungan dapat dibayar oleh para pengguna manfaatnya, serta dapat memelihara penyediaan dari jasa tersebut secara berkelanjutan. PJL kepada suatu DAS yang berkeadaan baik, akan berkaitan dengan ketersediaan supply air yang tersedia dengan kualitas yang terjamin. Skema PJL merupakan suatu instrument yang harus dirancang untuk memperbaiki alokasi sumberdaya alam pada tingkat DAS. Keberhasilan dari aplikasi sistem PJL tergantung kepada berbagai faktor; seperti bagaimana mengidentifikasi dengan baik, maupun tentang bagaimana cara mengkaitkan aspek tata guna lahan dengan penyediaan jasa lingkungan yang melibatkan supplier jasa di wilayah Hulu dengan para pemakai manfaat jasa tersebut di sebelah Hilir. Oleh karenanya, tidak setiap persoalan pengelolaan sumberdaya pada tingkat DAS dapat dipecahkan dengan menggunakan suatu skema PJL.

Dalam konteks daerah ailiran sungai (DAS), sistem PJL biasanya meliputi implementasi dari mekanisme pasar atau kelembagaan non-pasar. PJL ditujukan untuk mengkompensasi kepada para peggarap lahan di Hulu (upstream landowners) agar mereka dapat memodifikasi tata penggunaan lahan tertentu yang ada untuk konservasi. Upaya ini diharapkan dapat memberi dampak kepada perbaikan supply air baik dari segi kuantitas maupun kualitasnya. Jasa ini memberikan manfaat kepada sumberdaya air yang digunakan masyarakat di sebelah Hilir DAS (downstream water resource).

Permintaan (demand) terhadap perbaikan penawaran (supply) air bersih dapat diduga melalui permintaan turunan (derived demand) dengan metode tidak langsung (indirect method) yang merupakan alternatif penilaian sumberdaya air sebagai input kepada proses produksi ekonomi lokal. Agar PJL dapat menjadi bergulir lancar (viable), maka pendugaan permintaannya harus lebih tinggi dari nilai yang diperoleh untuk mengkompensasi 
para penyedia jasa lingkungan secara efektif, guna mencapai tujuan perubahan land use yang dimaksudkan. Informasi dasar yang terpercaya adalah penting untuk membuat rancangan sistem PJL beserta indikator yang benar yang harus dapat diidentifikasikan untuk mengukur dampak aplikasi dari sistem ini. Oleh karenanya perlu ada negosiasi dan bargaining game antara semua aktor-aktor terlibat. Dari negosiasi dibutuhkan terjadinya konsensus antara para aktor yang berkaitan dengan jasa-jasa dan aktivitas yang diusulkan.

Untuk bentuk land use yang dimaksud oleh PJL sebaiknya secara umum dikehendaki berbentuk sistem kehutanan, dengan menyadari akan jasajasa yang dapat diberikan oleh pepohonan dan belukarnya, terutama dari jenis tanaman endemik adalah merupakan yang terbaik. Tetapi bentuk wanatani (agro forestry), atau hutan campuran dengan tanaman keras yang dapat memberikan hasil kepada petani, disertai oleh upaya konservasi usaha tani juga dipandang sebagai penyediaan jasa lingkungan dalam DAS.

Sistem pembayaran jasa-jasa lingkungan perlu mengidentifikasi agents ekonomi yang bertanggung jawab kepada terjadinya eksternalitas lingkungan yang "positive", atau sebagai "penyedia" jasa yang akan menguntungkan bagi agents lain (para pengguna manfaat). Dengan membangun hubungan sebab-akibat yang diperlukan hubungan antara land use wilayah hulu (upstream) - kepada keadaan sumberdaya air di wilayah hilir (downstream) dalam DAS yang bersangkutan. Di samping itu, skema PJL bermaksud untuk membangun aliran informasi antara penyedia jasa-jasa dan pengguna manfaatnya untuk menyediakan institusi sebagai media pertukaran antara kedua jenis agents tersebut.

Penyusutan dan degradasi hutan lindung di Wilayah DAS Batang Anai yang menjadi hulu Sungai Batang Anai di kabupaten Padang Pariaman dan bermuara
Dasrizal, Ansofino, Erna Juita, Jolianis ke pantai Barat sebelah Utara kota Padang dan bertepatan dengan kawasan bandara Internasional Minangkabau, telah menyebabkan kawasan hilirnya ini rawan terhadap kejadian banjir. Untuk mengatasi keadaan ini diperlukan upaya konservasi lahan hutan dan air yang mengikutsertakan partisipasi masyarakat perdesaan di sekitarnya. Jika keadaan ini dibiarkan, maka sumberdaya air yang diperlukan oleh banyak pihak supplynya menjadi semakin menyusut di musim kering dan banjir di musim hujan, yang mengancam kehidupan masyarakat luas serta pembangunan ekonomi. Partisipasi masyarakat agar mencapai keberhasilan, diperlukan adanya pengukuhan hak-hak akses mereka kepada lahan hutan melalui kontrak jangka panjang (land tenure reforms). Oleh karena itu pelaksanaan sistem pembayaran bagi jasa-jasa perbaikan lingkungan menjadi sangat urgent untuk dilaksanakan dengan segera.

Skema PJL ini diharapkan dapat dilaksanakan secara langsung dan akan menjanjikan mekanisme kompensasi, dimana para penyedia jasa-jasa lingkungan dapat dibayar oleh para pengguna manfaatnya, serta dapat memelihara penyediaan dari jasa tersebut secara berkelanjutan. Sistem PJL kepada suatu DAS yang berkeadaan baik, akan berkaitan dengan ketersediaan supply air dengan kualitas yang terjamin. Skema PJL ini terdiri dari pembayaran atau kompensasi langsung oleh para pengguna jasa-jasa di Hilir (Kota, Padang) kepada para penyedianya di sebelah hulu (perdesaan). Skema PJL merupakan suatu instrument yang harus dirancang untuk memperbaiki alokasi sumberdaya alam pada tingkat DAS Batang Anai yang selama ini banyak gagal karena tidak mengikut sertakan kepentingan masyarakat setempat. Keberhasilan dari aplikasi sistem PJL tergantung kepada berbagai faktor; seperti bagaimana mengidentifikasi dengan baik, maupun tentang bagaimana cara mengkaitkan aspek tataguna lahan \& air 
dengan pemyediaan jasa lingkungan yang melibatkan keterkaitan supplier jasa di wilayah hulu (perdesaan) dengan para pemakai manfaat jasa tersebut di sebelah hilir (Perkotaan). Oleh karenanya, persoalan pengelolaan sumberdaya alam (lahan dan air) pada tingkat DAS Batang Anai diharapkan dapat dipecahkan dengan menggunakan suatu skema PJL.

Mengacu pada rumusan masalah yang telah diajukan di atas, maka tujuan penelitian ini adalah untuk melihat bagaimana model sistem pembayaran jasajasa lingkungan sebagai mekanisme transfer hulu-hilir dalam pengelolaan sumberdaya air dan lahan di wilayah DAS dapat diterapkan dalam pengelolaan dan konservasi wilayah DAS untuk mencegah semakin luasnya lahan kritis yang berdampak kepada terjadinya pemanasan global? Bagaimana membangun mekanisme pembayaran jasa-jasa lingkungan itu sebagai suatu pengaturan spontan?

Pada karakteristik fisik dan hidrologi sumberdaya air, maka dapat dikemukakan sifatnyanya sebagai berikut:

1. Air adalah selalu bergerak dari tempat yang tinggi ke rendah (mobile), khasnya dalam bentuk cair, mengalir, menguap, dan meresap sebagaimana bergerak mengikuti siklus hidrologi. Persoalan dalam sifatnya ini adalah bagaimana mengukur unit-unit khusus sumberdaya air, terutama karena sifat cair dan mengalirnya ini. Sehingga menghadapi persoalan tersebut ahli ekonomi mengatakan bahwa air adalah sumberdaya yang memerlukan biaya yang besar untuk mengumpulkannya (high-exclusion cost resources). Implikasi dari keadaan ini adalah bahwa penetapan property right yang khusus atas sumberdaya air ini sebagai basis bagi pertukaran ekonomi dan pasar adalah relative sulit dan mahal untuk ditetapkan dan diperkuat (establish and enforce). Oleh karena
Dasrizal, Ansofino, Erna Juita, Jolianis itu, jika penilaian ekonomi terhadap air diperlukan, maka penetapan property right harus ditegaskan lebih dahulu, karena ini merupakan necessary condition bagi berlakunya sistem pasar air.

2. Supply air cenderung menjadi sangat fluktuatif (highly variable), seperti halnya sumberdaya alam yang dapat diperbaharui, supply air mentah itu berada di luar kontrol manusia. Supply air cirinya adalah fluktuatif dan sulit diramalkan menurut ruang, waktu dan kuantitasnya, sehingga secara lokal ketersediaan air selalu berubah secara sistematis sesuai dengan perubahan musim, iklim global. Fluktuatif supply seperti banjir, kekeringan membawa konsekuensi ekonomi pada manusia karena dapat meningkatkan biaya hidup rumah tangga dan perusahaan, sehingga di sini diperlukan program pengurangan banjir dan mengatasi kekeringan dari pemerintah yang berdampak pada peningkatan anggaran pengeluaran pemerintah. Peningkatan anggaran pemerintahan jelas memberikan konsekuensi bagi penarikan pajak dan penentuan harga air yang harus ditempuh pemerintah, agar terjadi keseimbangan anggaran.

3. Air adalah pelarut alamiah yang bersifat universal, dalam kapasitas supplynya yang besar, air dapat menyerap limbah dan menghancurkan polutan, dan menghanytkan mereka ke laut, sehingga mengelola sumberdaya air sebagai pelarut bagi limbah cair maupun padat merupakan konsekuensi ekonomi bagi pengelolaan sumberdaya air secara terpadu. Artinya pengelolaan air bersih dan pengelolaan limbah air seperti dari rumah tangga (sewerage) merupakan bagian yang integral dalam penentuan harga air, rumah tangga dan industri bukan hanya membayar air bersih tetapi juga membayar pengolahan air limbahnya. 
4. Saling Keterkaitan antar pengguna sangat besar, aktifitas penggunaan air di hulu akan mempengaruhi aktifitas penggunaan air di hilir, dalam bentuk kualitas, kuantitas, dan waktu aliran yang dibutuhkan oleh pengguna di hilir. Sering keterkaitan ini menimbulkan pengaruh externalities or spill over yang menimbulkan biaya bagi aktifitas pengguna di hilir. Adanya eksternalitas ini berimplikasi pada pengenakan biaya ekonomi besar (full cost of economic activity) pada pengguna air di hilir. Oleh karena itu, harus tercermin di dalam utiliti masyarakat yang menggunakan air, agar penggunaan sumberdaya air mencapai titik optimalnya, sebagai syarat efisiensi penggunaan air.

5. Air Sering menjadi defisit hanya pada lokasi tertentu saja, karena variasi dalam supply dan permintaan lokal sehingga timbul masalah lokalisasi secara khas, dan kebijakan sering diperlukan untuk disesuaikan dengan kondisi lokal. Supply relatif air permukaan dan air tanah (surface and ground water) pada lokasi tertentu, tergantung pada variasi iklim (precipitasi dalam bentuk hujan) seperti halnya ketersediaan simpanan air tanah.

6. Fasilitas supply air memperlihatkan economies of large size, pengamanan daerah tangkapan air, penyimpanan, pengiriman air (khususnya air permukaan) semuanya memperlihatkan ukuran ekonomi yang besar terutama unit biaya-biaya yang diperlukan. Apabila terjadi penurunan biaya pada permintaan permintaan yang meningkat, maka penawaran air dapat menjadi lebih efisien secara ekonomi. Tetapi pendekatan biaya terendah (least-cost) sering dipakai pada tangkapan, penyimpanan, dan pengiriman air ke penduduk di wilayah perkotaan, biasanya oleh perusahaan umum air minum (PAM:
Dasrizal, Ansofino, Erna Juita, Jolianis milik pemerintah) yang dipandang sebagai monopoli alami (natural monopoly). Sejalan dengan ini, supply air untuk industri sering diserukan untuk menghindari monopoli harga (monopolistic pricing).

Sedangkan dari karakteristik permintaan air (water demand) jika dilihat dari perspektif para pengguna, maka dapat dikemukakan sifatnya sebagai berikut:

1. Karena perbedaan benefit yang diperoleh dari air, maka sangat bermanfaat untuk mengelompokkan tipe nilai sumberdaya air ke dalam lima (5) kelompok yakni: (Young, 2005).

1). Commodity benefits

2). Waste assimilation benefits

3). Public and private aesthetic, recreational, and fish and wildlife habitat value.

4). Biodiversity and ecosystem preservation

5). Social and cultural value.

2. Karakteristik ekonomi dari permintaan air beragam diantara garis continuum dari barang dan jasa rival ke non rival. Barang atau jasa dikatakan rival dalam konsumsinya adalah jika seseorang dalam mengkonsumsinya dapat mencegah orang lain dalam menggunakannya, barang dan jasa yang rival dalam konsumsinya adalah tipe yang dapat ditawarkan dan dialokasikan dengan proses pasar, dan sering disebut dengan private goods. Sedangkan barang yang bersifat non rival dalam konsumsinya berarti seseorang mengkonsumsinya tidak dapat mengeluarkan orang lain dalam menggunakannya juga, barang yang non rival sering disebut dengan public or collective goods. Sedangkan barang yang bersifat non rival dapat ditawarkan dan dialokasikan dalam proses non pasar, melalui penyusunan kontrak (contractual arrangement). Sementara itu, konsumsi air untuk pertanian, rumah tangga dan industri 
penggunaannya cenderung ke arah rival, dan dapat ditransaksikan di pasar (Young, 1996, 2005).

Tipe komoditi dari sumberdaya air telah melekat dalam konsumsi air pada air minum perorangan, sanitasi, aktifitas produksi pertanian, bisnis dan industri, istilah komoditi disini adalah karena sifat rival dalam pengkonsumsiannya. Oleh karena itu diperlukan penilaian ekonomi (economic valuation) yang sesuai dengan mekanisme pasar terhadap sumberdaya air sebagai komoditi dan bersifat rival dalam pengkonsumsiannya.

3. Air sering disebut sebagai barang yang memiliki biaya yang tinggi untuk pengadaan dan penguasaannya (highexclusion cost) karena sifat-sifat fisiknya, air sulit dan mahal pada terbatasnya penggunaan air karena mahalnya biaya produksinya.

4. Terdapat sifat penunggang bebas pada penggunaan air (free rider problem), karena adanya penolakan dari para pengguna air untuk membayar bagian yang yang mereka konsumsi, sedangkan mereka tidak dapat dikeluarkan dalam pengkonsumsiannya (non excluded), dengan anggapan bahwa air adalah public goods. Pada hal, dari sifat-sifat ekonomi sumberdaya air, maka air sebagian telah menjadi komoditi ekonomi yang memerlukan biaya yang besar untuk pengadaannya, maka adalah wajar dikenakan beban biaya terhadap pengkonsumsian air agar supply dapat tetap dipertahankan (establish), sesuai dengan permintaan yang terus meningkat sebagai akibat pertambahan jumlah penduduk dan aktifitas perekonomian.

5. Tipe komoditi benefits dari sumberdaya air dapat dilihat pada konsumsi air rumahtangga untuk memasak, sanitasi, yang berkontribusi kepada aktifitas produksi pertanian, bisnis komersial, dan industri. Apa
Dasrizal, Ansofino, Erna Juita, Jolianis yang disebut dengan nilai komoditi air adalah dibedakan oleh kenyataan bahwa adanya sifat rival dalam penggunaannya. Berarti seseorang yang menggunakan unit air tertentu harus mengeluarkan orang lain dari unit yang dia konsumsi, maka di sini air cenderung menjadi private goods.

6. Tipe penggunaan komoditi air oleh manusia dapat dibedakan berdasarkan sistem hidrologi alamiah yakni:

1). Penggunaan pengambilan air (offstream use or withdrawal use ); sering juga disebut dengan penggunaan konsumsi air (consumption use) seperti untuk minum, sanitasi, flousing toilet, air conditioner, dll. Pada tipe penggunaan air ini, maka air sebenarnya lebih mendekati pada kutub private goods karena berlaku sifat-sifat excludable, rivality, dan subtractable dalam pengkonsumsiannya

2). Penggunaan aliran arus air (instream use or non use value); sering juga disebut dengan penggunaan air bukan untuk dikonsumsi, tetapi sebagai input untuk keperluan lain (non consumption use) seperti untuk pembangkit tenaga listrik, rekreasi dan perburuan hewan liar, olah raga air, navigasi, turisme, taman kota, dll. Pada sifat penggunaan air ini, maka air dikategorikan sebagai public goods karena berlaku sifat-sifat non excludable, non rivality, non subtractable dalam pengkonsumsiannya.

7. Air adalah tipe komoditi yang bernilai rendah (low-valued commodity), nilai ekonomi per unit volume air cenderung relatif rendah, sehingga air sering juga disebut dengan barang "bulky". Biaya kapital, biaya energi dan biaya pentransportasiannya, cenderung menjadi relatif tinggi daripada nilai ekonomi air pada 
\begin{tabular}{llr} 
penggunaanya, & \multicolumn{2}{c}{ misalnya } \\
pengembalian bersih dari biaya & dersedia (return & net of \\
produksi yang & tersion $\quad$ cost) untuk biaya \\
production & perunit air & yang \\
penawaran & ain
\end{tabular} dikonsumsi oleh irigasi hanya sebesar $\$ 0,04$ per seribu $\mathrm{m}^{3}$ atau setara dengan Rp 225,- per $\mathrm{m}^{3}$. Sedangkan pengembalian bersih untuk biaya produksi air untuk perkotaan hanyalah sebesar $\$ 0,50$ per seribu $\mathrm{m}^{3}$ atau setara dengan $\mathrm{Rp} 18$,- per $\mathrm{m}^{3}$ (Young, 2005). Di bandingkan dengan pengembalian bersih biaya produksi air untuk irigasi di Indonesia lebih rendah lagi yakni hanya $\mathrm{Rp} 2$,- per $\mathrm{m}^{3}$ dan untuk air perkotaan hanyalah $\mathrm{Rp}$ 35,- per $\mathrm{m}^{3}$ (Anwar et al, 2004). Artinya di negara maju air untuk irigasi lebih mahal dibandingkan dengan air untuk keperluan rumahtangga, sebaliknya di Indonesia, air untuk irigasi lebih rendah dibandingkan dengan air untuk rumahtangga.

Dalam kaitannya dengan kelestarian sumberdaya air, harga air yang lebih sesuai (recovery cost) dengan biaya yang dikeluarkan, akan menyebabkan pengguna air akan berhemat dalam memakai air, pemerintah memiliki dana yang cukup untuk menutupi biaya operasional dan pemeliharaan infrastruktur sumberdaya air termasuk memberikan insentif kepada masyarakat di hulu dalam menjaga dan melestarikan hutan sebagai area tangkapan air.

Peralatan penting dalam ilmu ekonomi dalam menentukan harga dan pengunaan air yang efisien adalah model sederhana supply dan demand air sebagai model static karena air dianggap sebagai sumberdaya yang dapat diperbaharui (non renewable). Model ini mampu memberikan solusi yang efisien secara ekonomi. Efisiensi ekonomi memerlukan marginal value air menjadi sama diantara pengguna pada unit terakhir air yang dikonsumsi oleh setiap kelompok pengguna dan sama pada marginal cost
Dasrizal, Ansofino, Erna Juita, Jolianis dari supply air. Ketika supply air adalah inelastic sempurna; dimana supply air adalah tetap, maka demand menentukan harga, ini yang terjadi pada kasus PAM Jaya; dimana harga yang berlaku saat sekarang kurang responsive terhadap supply atau produksi air, tetapi ketika diterapkan harga marginal, maka responsnya sangat kuat. Pada keadaan demikian harga ditentukan oleh keseimbangan supply dan demand.

Daerah aliran sungai (DAS) secara sederhana, merupakan sebuah unit geografis yang meliputi seluruh bagian daerah yang dipisahkan diantara dua punggung bukit (Wantrup, 1961). DAS adalah daerah yang dialiri oleh satu sistem air permukaan seperti sungai, anak sungai, dan saluran airnya yang terkait (Gardiner dan Cole, 1992 dalam Bantacut, 1999). Oleh karena itu, sistem DAS terdiri dari lahan (land), air (water), dan tumbuhan (Vegetation). Sistem DAS juga meliputi aktifitas manusia yang bermukim diantaranya dan pada sistem atmospir yang berkaitan dengan daerah DAS.

DAS adalah suatu wilayah daratan yang merupakan satu unit tata air yang dibatasi oleh punggung bukit yang menampung, menjimpan, dan mengalirkan air hujan ke dalam sungai atau anak-anak sungai yang akhirnya bermuara ke laut melalui sungai utama. DAS terbentuk secara alamiah yang terdiri dari bagian hulu, tengah, dan hilir, serta berfungsi sebagai penampung air hujan, daerah resapan, daerah penjimpanan air, penangkap hujan, dan pengalirkan air. Selain merupakan system tata air, DAS juga merupakan media berbagai aktifitas manusia, sehingga penurunan kualitas ekosistem DAS berarti juga merupakan penurunan akan kualitas hidup manusia.

\section{METODE PENELITIAN}

Penelitian ini adalah dalam perspektif ekonomi sumberdaya air yang telah dikembangkan para ekonom yang 
tergabung dalam aliran ekonomi kelembagaan baru (new instituional economics) seperti Ronald Coase (1937, 1995) dan North (1990). Analisis menggunakan pendekatan ekonomi kelembagaan baru dalam analisisnya yang menekankan dua perspektif yakni teori tindakan pilihan bersama dalam ekonomi (collective choice theory) dan teori permainan (the games theory).

Peralatan analisis yang digunakan adalah analisis ekonometrika, analisis dinamik dan analisis efisiensi. Analisis ekonometrika ini digunakan untuk menurunkan fungsi demand dan supply air diantara kelompok penguna air, oleh karena sifat permintaan air tersebut adalah berupa final demand dan derived demand, maka digunakan model penyesuaian aliran permintaan (flow adjustment demand model). Kemudian dengan menggunakan mekanisme alokasi air yang didasarkan atas pasar, akan diperoleh harga keseimbangan air di pasar, sehingga akan menjadi acuan untuk melakukan analisis penentuan alokasi yang optimum bagi masing-masing pihak pengguna air.

\section{PEMBAHASAN}

\section{Gambaran Umum Daerah Aliran Sungai Batang Anai}

Batang Anai adalah salah satu sungai yang terdapat di provinsi Sumatera Barat. Sungai ini mengalir dari arah hulu ke hilir sungai melalui beberapa daerah dalam wilayah kabupaten Tanah Datar dan kabupaten Padang Pariaman. Batang Anai berhulu di sekitar kaki gunung Singgalang dan sebelum bermuara di Samudera Hindia, aliran Batang Anai ini bertemu dengan aliran Batang Kandis. Dari hasil observasi, berbagai daerah aktivitas manusia yang dilewati aliran Batang Anai tentu akan banyak air yang masuk ke dalam sungai ini.

Sungai Batang Anai mulai dari hulu sampai ke hilir banyak mengalami pencemaran dari manusia. Masukan limbah dari aktivitas manusia, organik
Dasrizal, Ansofino, Erna Juita, Jolianis yang berasal dari pemukiman, pasar, adanya kerusakan badan sungai seperti pembesaran jalan, adanya galian $\mathrm{C}$ dan aliran masuk PLTA Lubuk Simantuang serta berbagai limbah industri yang masuk dibagian hilirnya. Adanya aktivitas manusia tersebut, secara langsung maupun tidak langsung akan dapat mempengaruhi kualitas air dan kondisi fisik badan perairan yang pada akhirnya akan mempengaruhi biota yang hidup di dalam sungai tersebut.

Daerah Irigasi Anai terletak pada Kabupaten padang Pariaman dengan luas areal 13.604 Ha. Sumber air diambil dari Bendung Anai yang dibangun pada tahun 1989, dan terletak di daerah Asampulau dengan jarak sekitar $6 \mathrm{Km}$ dari Lubuk Alung. Semenjak beroperasi Daerah Irigasi Anai menggunakan pola Tanam Palawija Padi - Padi, yakni musim tanam palawija dimulai bulan Februari berakhir bulan Mei kemudian dilanjutkan dengan tanaman padi antara bulan Juni dan September, seterusnya musim tanam kedua mulai Oktober dan berakhir pada bulan Januari.

\section{Potensi, Penggunaan dan Tekanan pada Sumberdaya Air di Wilayah DAS Batang Anai}

Wilayah provinsi Sumatera Barat memiliki luas $\pm 42.297,30 \mathrm{~km}^{2}$ dengan jumlah penduduk menurut sensus tahun 2010 berjumlah 4.845 .998 jiwa, dengan kepadatan sebesar 114,56 jiwa/kilometer. Wilayah yang paling padat adalah Kota Padang dengan penduduk sebanyak 833.584 jiwa, dengan kepadatan 1.214 jiwa $/ \mathrm{km}^{2}$. Luas lahan budidaya di Sumatera Barat adalah seluas 23.255,77 $\mathrm{km}^{2}$ atau sebesar 54,98\% dan luas kawasan lindung adalah seluas $18.996,53 \mathrm{~km}^{2}$ atau sebesar 44,91\%. Penggunaan lahan didominasi oleh hutan lebat yang mencapai $56,40 \%$. Hal ini memperlihatkan bahwa potensi sumberdaya airnya sangatlah besar, karena hutan lebat ini merupakan hulu dari sungai-sungai besar yang mengalir ke pantai Barat Sumatera dan bahkan ada 
yang menjadi hulu bagi sungai-sungai besar yang mengalir ke pantai Timur seperti Batanghari.

Di samping memiliki jumlah penduduk yang cukup padat, maka wilayah Sumatera Barat juga memiliki 19 jumlah daerah aliran sungai (DAS) yang dikelompok ke dalam empat satuan wilayah sungai yaitu: satuan wilayah sungai (SWS) Anai, Kuranji, Arau, Mangau Antokan disingkat dengan SWS Akuaman, SWS Silaut Tarusan, SWS Masang Pasaman, dan SWS Pulau Siberut, Pagai Sipora. Potensi sumberdaya air pada enam SWS ini diperkirakan adalah sebesar 53.418 juta $\mathrm{m}^{3} /$ tahun. Apabila ditambah dengan potensi sumberdaya air tanah yang diperkirakan berjumlah 18.164 juta $\mathrm{m}^{3} /$ tahun, maka potensi sumberdaya air total Sumatera Barat itu adalah diperkirakan sebanyak 71.582 juta $\mathrm{m}^{3} /$ tahun. Gambaran besarnya potensi sumberdaya air ini dapat dibandingkan dengan potensi sumberdaya air pulau Sumatera yang mencapai 738 milyar m3/tahun, sehingga besarnya potensi sumberdaya air Sumatera Barat itu adalah $9,70 \%$ dari ketersediaan sumberdaya air pulau Sumatera. Ketersediaan sumberdaya air ini merupakan potensi air irigasi bagi wilayah Sumatera Barat. Potensi sungai untuk jaringan irigasi ini sangat besar, terdapat 14 daerah irigasi dengan luasan areal irigasi mencapai 89.391 ha. Potensi sumberdaya air lainnya adalah berasal dari daerah rawa, dimana di wilayah Sumatera Barat luas wilayah rawa itu mencapai 309.459 ha, dan yang sudah dimanfaatkan adalah sebesar 27.722 ha atau $8,96 \%$, sisanya sebesar 281.737 ha masih belum dimanfaatkan. Sumberdaya rawa yang sudah dimanfaatkan untuk sawah lebih dominan yakni mencapai 15.026 ha atau sebesar 54,20\%.

Potensi sumberdaya air lainnya adalah danau, terdapat empat danau besar di Sumatera Barat yakni danau Singkarak dengan luas 13.000 ha dan luas wilayah tangkapan airnya (catchment area) adalah
Dasrizal, Ansofino, Erna Juita, Jolianis 107.600 ha dan besarnya volume ketersediaan airnya adalah sebesar 1.656 juta $\mathrm{m}^{3}$, yang terletak di kabupaten Solok dan Tanah Datar. Di samping itu, Danau Maninjau dengan luas 9.900 ha dan wilayah tangkapan airnya adalah 24.800 ha dan volume ketersediaan airnya adalah sebesar 558 juta $\mathrm{m}^{3}$ yang banyak dimanfaatkan untuk PLTA. Terakhir adalah danau Di atas dan Danau di Bawah yang memiliki luas sebesar 3.100 ha dengan luasan wilayah tangkapan airnya adalah 6.900 ha, yang mampu menyiapkan volume air danau sebesar 65 juta $\mathrm{m}^{3}$. Potensi sumberdaya air berikutnya adalah embung, di wilayah Sumatera Barat terdapat 185 embung, yang dipergunakan untuk keperluan irigasi oleh masyarakat setempat. Total potensi embung seluruhnya adalah $505.800 \mathrm{~m}^{3}$, paling besar pada kabupaten Pesisir Selatan dan 50 Kota.

Berdasarkan kepada potensi sumberdaya air yang telah dikemukakan di atas, maka terlihat bahwa wilayah Sumatera Barat memiliki potensi sumberdaya air yang lebih dari cukup untuk memenuhi kebutuhan terhadap penggunaan air untuk keperluan irigasi, air minum, dan penggunaan untuk industri dan penggunaan untuk pembangkit tenaga listrik. Potensi sumberdaya air yang besar dari total 71.582 juta $\mathrm{m}^{3} /$ tahun itu adalah SWS Silaut yakni mencapai $18.136,89$ juta $^{3} /$ tahun atau sebesar $25,34 \%$ yang terdapat di kabupaten Pesisir Selatan, disusul oleh SWS Batang Anai (Akuaman) yang mencapai $16.499,42$ juta $\mathrm{m}^{3} /$ tahun atau sebesar 21,65\% yang terletak di kabupaten Padang Pariaman dan Kota Padang, serta potensi sumberdaya air dari SWS Batang hari sebesar 8.079, 24 juta $\mathrm{m} 3 /$ tahun atau sebesar $11,29 \%$ yang terletak di kabupaten Dharmasraya dan Solok Selatan. Pemanfaatan sumberdaya air untuk SWS Akuaman mencapai 1.869,66 juta $\mathrm{m}^{3} /$ tahun yang terdiri dari penggunaan oleh irigasi pertanian, intake PDAM untuk pengelolaan air minum dan 
penggunaan arus air oleh PLTA. Diantara satuan wilayah sungai yang ada, maka pemanfaatan sumberdaya air yang masih kecil sekali adalah pada SWS Kampar dan SWS Batang hari yang masing-masingnya mencapai 439,92 juta $\mathrm{m}^{3} /$ tahun dan 689,98 juta $\mathrm{m}^{3} /$ tahun.

Potensi sumberdaya air di wilayah Sumatera Barat yang besar itu belum termanfaatkan sebesar $88 \%$ hanya sebanyak $12 \%$ yang baru termanfaatkan. Sedangkan pemanfaatan yang dominan baru untuk keperluan air irigasi, di samping penggunaan air untuk PDAM yang mengolah kebutuhan air bersih penduduk. Penggunaan air untuk industry relative kecil sekali, karena sejalan dengan masih belum berkembangnya industry di wilayah Sumatera Barat. Pada wilayah DAS Batang Anai, pemanfaatan sumberdaya airnya didominasi oleh pengguna air irigasi terutama di kabupaten Padang Pariaman, sedangkan untuk penggunaan air PDAM belum ada. Namun penggunaan air untuk PLTA hanya memanfaatakan aliran sungai ini untuk mengalirkan arus air dari Danau Singkarak ke aliran Sungai Batang Anai. Sehingga penggunaan sumberdaya air pada DAS Batang Anai relatif belum optimal. Itulah sebabnya, pada saat debit puncak, maka DAS Batang Anai ini menimbulkan masalah banjir bagi wilayah hilirnya yang terletak di dekat Bandara Internasional Minangkabau.

Disamping banyaknya daerah aliran sungai, wilayah Sumatera Barat juga memiliki curah hujan yang tinggi, sehingga daerah pergunungan yang subur dan diiringi oleh tingginya curah hujan, maka telah menyebabkan tingkat resapan air (precipitation system) cukup tinggi. Menurut data yang dikeluarkan oleh Dinas Geologi dan Tata Lingkungan (DGTL) Bandung, (2003) dan BMKG Sumatera Barat tahun 2008, ternyata laju precipitasi di wilayah Sumatera Barat mencapai 126,9 juta $\mathrm{m}^{3} /$ tahun, maka dengan laju precipitasi sebesar itulah yang mampu menyediakan
Dasrizal, Ansofino, Erna Juita, Jolianis sumberdaya air permukaan dan air tanah bagi wilayah Sumatera Barat.

Besarnya laju precipitasi yang ada, kemudian tentunya akan mengalami tiga proses selanjutnya yakni penguapan (evaporation) yang sangat tergandung kepada tingkat kekeringan suhu udara, sehingga laju penguapan di wilayah Sumatera Barat adalah sebesar 1,500 mm. Sedangkan laju resapan air yang masuk kedalam kantong-kantong air tanah (infiltration)mencapai 20,8 juta $\mathrm{m}^{3} /$ tahun, yang mengisi ketersediaan air tanah di wilayah Sumatera Barat. Terakhir besarnya air limpahan atau air yang mengalir pada permukaan tanah yang apabila besar disebut dengan banjir itu adalah sebesar $2000 \mathrm{~mm} /$ tahun.

Total penggunaan air selama ini berjumlah 6.289 juta $\mathrm{m}^{3} /$ tahun atau sebesar $8,65 \%$, yang bersumber dari air permukaan dan air tanah, dimana volume air permukaan adalah berjumlah 53.418 juta $\mathrm{m}^{3} /$ tahun dan volume air tanah yang mengisi kantong-kantong air tanah atau cekungan air tanah (CAT) di wilayah Sumatera diperkirakan berjumlah 18.164 juta $\mathrm{m}^{3} /$ tahun. Sisa penggunaan air permukaan dan air tanah yang ada, adalah berupa air limpahan yang mengalir ke laut lepas sebanyak 65.293 juta $\mathrm{m}^{3} /$ tahun atau sebesar $91,21 \%$.

Penggunaan sumberdaya air yang relative masih terbatas ini, karena lebih banyak mengalir ke laut lepas, dengan menggunakan sejumlah asumsi bahwa penggunaan air untuk irigasi sebesar $1,2 \mathrm{~m}^{3} /$ ha (Suciati, 2004), penggunaan air individu menurut standard WHO itu adalah 125 liter/orang/hari (Ansofino, 2005), maka dengan asumsi ini dipergunakan untuk menghitung penggunaan air untuk berbagai sector. Penggunaan air oleh rumah tangga atau domestic yang menggunakan air olahan PDAM yang mencapai 133 juta $\mathrm{m}^{3} /$ tahun atau sebesar $2,11 \%$ dari total penggunaan air, ternyata pengguna volume air paling besar itu adalah sector pertanian yakni 6.154 juta 
$\mathrm{m}^{3} /$ tahun atau sebesar $97,85 \%$ dari total penggunaan air permukaan dan air tanah yang ada selama ini, dan sector industry adalah sebesar 2 juta $\mathrm{m}^{3} /$ tahun atau sebesar 0,018 juta $\mathrm{m}^{3} /$ tahun.

Berdasarkan kepada kondisi penggunaan air di wilayah Sumatera Barat yang didominasi oleh penggunaan sector pertanian, memperlihatkan bahwa air belum dialirkan kepada pengguna yang bernilai efisien, karena sector pertanian termasuk pengguna yang belum memberikan nilai (water pricing) pada penggunaan air, sehingga pengguna ini disebut memiliki volume yang besar tetapi nilainya rendah (hight volume, low value), sehingga penggunaan air belum sesuai dengan prinsip efisiensi.

Berikutnya, akan dikemukakan ketersediaan sumberdaya air pada wilayah DAS Batang Anai yang menjadi sasaran penelitian ini. Wilayah DAS Batang Anai memiliki luas sebesar $646,20 \mathrm{~km}^{2}$ tahun 2011 telah berkurang dari luas tahun 1996 seluas 904,55 $\mathrm{km}^{2}$ atau sebesar 28,56\% yang disebabkan oleh semakin bertambahnya jumlah penduduk dan semakin berkurangnya luasan hutan yang menjadi area tangkapan airnya. Semakin berkurangnya, luasan DAS ini tentunya akan berdampak kepada ketersediaan air yang ada.

Besarnya curah hujan total tahun 2001 sebesar $3.344 \mathrm{~mm} /$ tahun, telah mengalami peningkatan menjadi $4.509 \mathrm{~mm}$ tahun 1996 dan terus meningkat menjadi $4.672 \mathrm{~mm}$ tahun 2011, hal ini tentu saja berkaitan dengan pola perubahan cuaca ektrim akibat pemanasan global (global warming), sehingga intensitas hujan di wilayah DAS Batang Anai ini lebih tinggi. Ketersediaan air bulanan pada DAS Batang Anai tahun 1996 adalah berjumlah 254,60 juta $\mathrm{m}^{3} /$ tahun dan telah mengalami penurunan tahun 2011 menjadi 127,38 juta $\mathrm{m}^{3} /$ tahun. Data ini menunjukkan bahwa pada satu sisi terjadi pengurangan luasan DAS Batang Anai, tetapi pada sisi lain curah hujan justru semakin bertambah,
Dasrizal, Ansofino, Erna Juita, Jolianis tetapi ketersediaan sumberdaya air justru semakin berkurang, maka hal ini mengindikasikan bahwa fenomena terjadinya banjir pada saat musim hujan puncak yakni bulan September sampai dengan Desember setiap tahunnya. Oleh karena berkurangnya wilayah tangkapan akibat pembukaan lahan hutan di DAS hulunya, sehingga kemampuan untuk menjimpan air pada musim hujan menjadi berkurang, akibatnya wilayah hilir DAS Batang Anai sangat rentan dengan terjadinya air limpasan atau banjir.

Semakin meningkatnya curah hujan yang disebabkan oleh perubahan cuaca ekstrim tentunya berdampak kepada fenomena kejadian banjir di sepanjang aliran Batang Anai. Menurut Eriza, et al (2008) kejadian banjir dengan kapasitas puncak pada DAS Batang Anai mencapai $766 \mathrm{~m}^{3} /$ detik ditambah dengan wilayah hilir Batang Anai ini ternyata bergabung menjadi satu aliran sungai menuju muara di wilayah Duku atau dekat Bandar Internasional Minangkabau dengan sungai Talao Bungo dan Batang Kandis yang masing-masing debit puncaknya mencapai $106 \mathrm{~m}^{3} /$ detik dan $80 \mathrm{~m}^{3} /$ detik. Artinya, pada saat debit puncak, aliran air Batang Anai menyebabkan banjir dan pada debit minimum menyebabkan kekurangan aliran. Oleh karena itu diperlukan penanganan kejadian banjir di hilir Batang Anai dan Batang Kandis yang menjadi tempat pertemuan hilir kedua sungai ini.

\section{Kelembagaan pengelolaan Sumberdaya Air di Wilayah DAS Batang Anai}

Badan yang berwenang dalam mengelola DAS Batang Anai adalah Dinas PSDA provinsi Sumatera Barat dan Balai Wilayah Sungai Sumatera V dan Badan Pengelolaan DAS Agam- Kuantan. Lembaga pengguna sumberdaya air di DAS Batang Anai ini adalah pengguna dosmestik dalam hal ini di wakili oleh PDAM Kota Padangpanjang, dan penduduk di wilayah DAS Batang Anai yang meliputi kabupaten Tanah Datar, 
Kota Padangpanjang, Kabupaten Padang Pariaman, dan Kota Padang. Petani pemakai air P3A kabupaten Padang Pariaman.

\section{Perilaku Permintaan dan \\ Penawaran Sumberdaya Air di Wilayah DAS Batang Anai}

Perilaku permintaan dan penawaran sumberdaya air di wilayah DAS Batang Anai ini dapat dilihat dari kebutuhan penggunaan air oleh permintaan domestik, atau penduduk yang membutuhkan air, penggunaan oleh irigasi dan penggunaan oleh industri. Namun, dalam pengambilan manfaat sumberdaya air saat ini di DAS Batang Anai, pengguna sektor industri ternyata tidak ada, yang dominan adalah pengguna air irigasi dan rumahtangga.

Kebutuhan air penduduk yang berada di dalam wilayah DAS Batang Anai semuanya berjumlah 253.106 jiwa yang terdiri dari tiga wilayah yakni Kota Padang dengan nagari Koto Tangah berpenduduk sebanyak 52.514,79 jiwa atau 20,75\% dari total penduduk yang berada di wilayah DAS Batang Anai. Penduduk yang berada di wilayah DAS Batang Anai ini didominasi oleh penduduk kabupaten Padang Pariaman yang mencapai 125.912 jiwa atau 49,75\%, sedangkan penduduk wilayah DAS yang berasal dari kabupaten Tanah Datar berjumlah 23.391 jiwa atau sebesar 9,24\%. Disamping itu, penduduk di wilayah DAS Batang Anai yang berada di Kota Padangpanjang adalah sebanyak 51.289 jiwa atau sebesar 20,26\%. Sehingga wilayah DAS Batang Anai dominan didiami oleh penduduk kabupaten Padang Pariaman sebanyak 49,75\%, disusul oleh Kota Padang sebanyak 20,75\% dan Kota Padangpanjang sebesar 20,26\%

Jumlah penggunaan air total penduduk yang berada di wilayah DAS Batang Anai adalah berjumlah 6.439.233 $\mathrm{m}^{3} /$ tahun/orang, hal ini hanya sebesar 5,04\% dari ketersediaan air yang ada pada DAS Batang Anai ini yagn berjumlah tahun 2011 adalah 127,38 juta $\mathrm{m}^{3}$ /tahun. Pengguna air DAS Batang Anai yang
Dasrizal, Ansofino, Erna Juita, Jolianis paling besar adalah penduduk pada kabupaten Padangpariaman 1.332.183 $\mathrm{m}^{3} /$ tahun atau sebesar $1,04 \%$. Artinya penggunaan air DAS Batang Anai untuk keperluan rumahtangga masih cukup kecil.

Selanjutnya, penggunaan air DAS Batang Anai untuk keperluan irigasi, adalah digunakan untuk daerah irigasi (DI) Batang Anai di Kabupaten Padang Pariaman dengan luas areal irigasi mencapai 13.604 ha tahun 2011, dengan kebutuhan akan aliran air adalah sebesar $10,15 \mathrm{~m}^{3} /$ detik. Apabila diasumsikan penggunaan air untuk keperluan irigasi menurut standard IFRI (2003) adalah sebesar 1,2 $\mathrm{m}^{3} / \mathrm{ha}$, maka kebutuhan air untuk lahan sawah yang akan diairi oleh air Batang Anai ini adalah sebanyak $16.324,8 \mathrm{~m}^{3} / \mathrm{ha}$. Jumlah ini tentunya sangat kecil sekali jika dibandingkan dengan ketersediaan air pada DAS Batang Anai. Artinya, ketersediaan air untuk keperluan irigasi masih cukup besar potensinya, justru aliran yang lepas sampai ke laut masih sangat besar yakni mencapai 4,38 $\mathrm{m}^{3} /$ detik (Dinas PSDA Sumbar, 2011).

Aliran air DAS Batang Anai sejak dari hulunya sampai ke wilayah hilirnya telah menjadi muara bagi sungai-sungai kecil di sekitarnya, setidaknya ada 14 anak sungai kecil yang kemudian bergabung dengan Batang Anai ini yakni:

1. Batang Singgalang Kaciak dengan debit $0,33 \mathrm{~m}^{3} /$ detik

2. Batang Sinagalang Gadang dengan debit $0,12 \mathrm{~m}^{3} /$ detik

3. Batang Kapuyuk dengan debit 0,11 $\mathrm{m}^{3} /$ detik

4. Batang Tikayu dengan debit 0,25 $\mathrm{m}^{3} /$ detik

5. Batang Sipisang Gadang dengan debit $0,55 \mathrm{~m}^{3} /$ detik

6. Buangan PLTA Singkarak dengan debit $0,34 \mathrm{~m}^{3} /$ detik

7. Batang Asam Pulau dengan debit $1,83 \mathrm{~m}^{3} /$ detik

8. Batang Sangkir dengan debit 0,16 $\mathrm{m}+/$ detik 
9. Batang Sekayan dengan debit 0,08 $\mathrm{m}^{3} /$ detik

10. Batang Salibutan dengan debit 1,25 $\mathrm{m}^{3} /$ detik

11. Batang Surantih Kecil dengan debit $0,31 \mathrm{~m}^{3} /$ detik

12. Batang Salisikan dengan debit 0,47 $\mathrm{m}^{3} /$ detik

13. Batang Buluh dengan debit 0,20 $\mathrm{m}^{3} /$ detik

14. Batang Kandis dengan debit 1,46 $\mathrm{m}^{3} /$ detik

Menurut perhitungan Dinas PSDA provinsi Sumatera Barat jumlah kebutuhan air $7.257 \mathrm{~m} 3 /$ bulan dan jumlah air yang tersedia adalah sebesar $11.801 \mathrm{~m} 3 /$ bulan, sehingga ketersediaan air bagi pengguna air pada DAS Batang Anai ini mengalami surplus. Artinya, potensi penggunaan air bagi penduduk dan daerah irigasi di daerah wilayah DAS ini masih cukup tinggi.

\section{PENUTUP}

\section{Kesimpulan}

Berdasarkan hasil penelitian yang telah dilakukan dapat ditarik beberapa kesimpulan sebagai berikut :

1. Sumatera Barat memiliki potensi sumberdaya air yang lebih dari cukup untuk memenuhi kebutuhan terhadap penggunaan air untuk keperluan irigasi, air minum, dan penggunaan untuk industri dan penggunaan untuk pembangkit tenaga listrik.

2. Pada wilayah DAS Batang Anai, pemanfaatan sumberdaya airnya didominasi oleh pengguna air irigasi terutama di kabupaten Padang Pariaman, sedangkan untuk penggunaan air PDAM belum ada. Namun penggunaan air untuk PLTA hanya memanfaatkan aliran sungai ini untuk mengalirkan arus air dari Danau Singkarak ke aliran Sungai Batang Anai sehingga penggunaan sumberdaya air pada DAS Batang Anai relatif belum optimal. Itulah sebabnya, pada saat debit puncak,
Dasrizal, Ansofino, Erna Juita, Jolianis maka DAS Batang Anai ini menimbulkan masalah banjir bagi wilayah hilinnya yang terletak di dekat Bandara Internasional Minangkabau

3. Kondisi penggunaan air di wilayah DAS Batang Anai didominasi oleh penggunaan sektor pertanian, memperlihatkan bahwa air belum dialirkan kepada pengguna yang bernilai efisien, karena sector pertanian termasuk pengguna yang belum memberikan nilai (water pricing) pada penggunaan air, sehingga pengguna ini disebut memiliki volume yang besar tetapi nilainya rendah (hight volume, low value), sehingga penggunaan air belum sesuai dengan prinsip efisiensi.

4. Luas wilayah DAS Batang Anai mengalami pengurangan dari tahun ke tahun yang disebabkan oleh semakin bertambahnya jumlah penduduk dan semakin berkurangnya luasan hutan yang menjadi area tangkapan airnya. Semakin berkurangnya, luasan DAS ini tentunya akan berdampak kepada ketersediaan air yang ada

5. Badan yang berwenang dalam mengelola DAS Batang Anai adalah Dinas PSDA provinsi Sumatera Barat dan Balai Wilayah Sungai Sumatera V dan Badan Pengelolaan DAS Agam-Kuantan. Lembaga pengguna sumberdaya air di DAS Batang Anai ini adalah pengguna dosmestik dalam hal ini di wakili oleh PDAM Kota Padangpanjang, dan penduduk di wilayah DAS Batang Anai yang meliputi kabupaten Tanah Datar, Kota Padangpanjang, Kabupaten Padang Pariaman, dan Kota Padang. Petani pemakai air P3A kabupaten Padang Pariaman

6. Dalam pengambilan manfaat sumberdaya air saat ini di DAS 
Batang Anai, pengguna sektor industri ternyata tidak ada, yang dominan adalah pengguna air irigasi dan rumahtangga

7. Jumlah penggunaan air total penduduk yang berada di wilayah DAS Batang Anai adalah berjumlah 6.439.233 $\mathrm{m} 3 /$ tahun/orang, hal ini hanya sebesar $5,04 \%$ dari ketersediaan air yang ada pada DAS Batang Anai ini yang berjumlah tahun 2011 adalah 127,38 juta m3/tahun. Pengguna air DAS Batang Anai yang paling besar adalah penduduk pada kabupaten Padangpariaman 1.332.183 m3/tahun atau sebesar 1,04\%.Artinya penggunaan air DAS Batang Anai untuk keperluan rumahtangga masih cukup kecil.

8. Penggunaan air DAS Batang Anai untuk keperluan irigasi adalah digunakan untuk daerah irigasi (DI) Batang Anai di Kabupaten Padang Pariaman dengan luas areal irigasi mencapai 13.604 ha tahun 2011, dengan kebutuhan akan aliran air adalah sebesar 10,15 m3/detik, kebutuhan air untuk lahan sawah yang akan diairi oleh air Batang Anai ini adalah sebanyak 16.324,8 m3/ha. Jumlah ini tentunya sangat kecil sekali jika dibandingkan dengan ketersediaan air pada DAS Batang Anai. Artinya, ketersediaan air untuk keperluan irigasi masih cukup besar potensinya, justru aliran yang lepas sampai ke laut masih sangat besar.

\section{Saran}

Berdasarkan hasil penelitian yang telah dilakukan dapat disampaikan beberapa saran sebagai berikut :

1. Dinas PSDA provinsi Sumatera Barat dan Balai Wilayah Sungai Sumatera V perlu mengambil kebijakan dalam upaya mengoptimalkan pemanfaatan sumberdaya air DAS Batang Anai untuk kebutuhan terhadap penggunaan
Dasrizal, Ansofino, Erna Juita, Jolianis untuk industri dan penggunaan untuk pembangkit tenaga listrik dan bukan saja digunakan untuk keperluan irigasi dan keperluan rumah tangga.

2. Perlu dilakukan penanaman pohon penghijau "Penanaman Sejuta Pohon" di sekitar DAS Batang Anai agar dapat mengurangi pengurangan luas wilayah DAS dari tahun ke tahun

3. Dinas PSDA provinsi Sumatera Barat dan Balai Wilayah Sungai Sumatera V perlu membangun kembali ekosistem wilayah DAS, melalui pengelolaan terpadu antara sumberdaya air dan lahan dalam suatu daerah aliran sungai yaitu dengan membangun sistem transfer hulu-hilir dalam pemanfaatan sumberdaya air dan lahan yang terkait dengan basis perekonomian masyarakat di wilayah DAS.

4. Perlu ditetapkan model pembayaran jasa-jasa lingkungan (PJL) terhadap pihak yang memperoleh manfaat dalam penggunaan sumberdaya air dan lahan seperti PDAM, Industri, dan rumahtangga serta petani

5. Mendorong program-program pengentasan kemiskinan di wilayah Hulu daerah aliran sungai (DAS) melalui sistem insentif berupa pembayaran untuk jasa lingkungan kepada petani miskin yang mau memberikan jasa perbaikan lingkungan

\section{DAFTAR PUSTAKA}

\subsection{2/economica.2012.v1.i1.102}

Abdalla, C. W. (1994). Groundwater Value from Avoidance Cost Studies: Implication for Policy and Future Research, American Journal of Agricultural Economic, 76, November 1994.

Amman, H.M, dan Kumar, A. (2001). Land Tenure Conflict Resolution: A Game Theoretic Approach in the 
Narok District in Kenya, IIED, London.

Baumann, D. D. (1997). Urban Water Demand Management and Planning, Mc. Graw-Hill, Inc, New York.

Bergstrom, J. C, et al (1996). Assessing The Economic Benefits of Groundwater for Environmental Policy Decisions, Water Resource Bulletin, American Water Resources Association, Washington D.C.

Briscoe, J. (1997). Managing Water as an Economic Good: Rules for Reformers, World Bank, Washington D.C.

Dick, R. M. (1996). Groundwater Markets in Pakistan: Partisipation and Productivity, Research Report 105, IFFRI, Washington D.C.

Dinar, A. dan Wolf, A. (1997). Economic and Political Considerations in Regional Cooperation Models, Agricultural and Resources Economics Review, April, 1997, tt.

Dinar, A, Rosegrant, M. W, dan Dick, R. M. (1997). Water Allocation Mechanisms: Principles and Examples, Policy Research Working Paper 1779, Wolrd Bank, IFFRI, tt.

Dumairy. (1992). Ekonomika Sumberdaya Air, BPFE UGM, Yogyakarta.

Easter, K. W, Rosegrant, M.W. Dinar, A. (1999). Formal and Informal Markets for Water: Institutions, Performance, and Constrains, The World Bank Research Observer, Vol. 14, No: 1, February 1999, pp. 99-116.

Enders, W. (1995). Applied Econometric Time Series, Jhon Wiley \& Son Inc, New York.

Fahmi, I. (1991). Derived Demand for Irrigation Water in Burdekin River Irrigation Area, Tesis Masters, University of New England.
Dasrizal, Ansofino, Erna Juita, Jolianis

Faux, J, and Perry, G. M. (1999). Estimation Irrigation Water Value Using Hedonic Price Analysis, Land Economics, Volume 75, No: 3 August 1999, University of Wisconsin Press.

Fauzi, A. (2000). Valuasi Ekonomi Sumberdaya Pesisir, Makalah Disampaikan Pelatihan "Pengelolaan Wilayah Pesisir \& Pulau-Pulau Kecil, Proyek Kerjasama IPB- New Guinea University of Technology, Bogor 20-25 Maret 2000.

Frank, R.H. (2003). Micro Economic and Behavior, McGraw-Hill, New York.

Green, C. (2003). Handbook of Water Economic; Principles and Practice, John Wiley and Son West Sussex, England.

Hanemann, W. M. (1994). Price and Rate Structure, Mc Graw- Hill, Inc, New York.

Hartwick, J.M, dan Olewiler, N.D.(1998). The Economies of Resource Use, Addison Wesley Educational Publishers, Massachusetts.

Hasan, Z, dan Bawayusa, M. (1996). Guidelines for the Establishment of Appropriate Irrigation Water Pricing Policies and Structures in The ESCAP Region, ESCAP, Jakarta.

Hatmoko, W, Barwawi, M, dan Amirwandi. (2002). Sistem Pendukung Keputusan Untuk Perencanaan Pengembangan Wilayah Sungai, Buletin Pusair Vol. XI, No: 37 April 2002.

Hayami, Y. (2000). Development Economics; From the Proverty to the Wealth of Nations, Oxford University Press.

Hearne, R. R. dan Easter, K. W. (1996). The Economic and Financial Gains from Water Markets in Chile, Agricultural Economics, Vol. 15, No: 3 Januari 1997, Elseveir, tt. 
Hendry, D..F. (1996). Dynamic Econometrics, Oxford University Press, New York.

Herringthon, P. (1999). Household Water Pricing in OECD Countries, www.oils.org.eng. OECD, Paris.

Hewitt, J. A dan Haneman, W. M. (1995). A Discrete/ Continuous Choice Approach to Residential Water Demand Under Block Rate Pricing, Land Economics, Vol. 71, No: 2, May 1995.

Holland, D, dan Wyeth, P. (1993). SAM Multipliers: Their Decomposition, Interpretation and Relationship to Input-Output Multipliers, Research Bulletin XB 1027, Washington State University.

Lonergan, S. C dan Brooks, D. B. (1992). Watershed; The Role Of Fresh Water in the Israeli- Palestinian Conflict, International Development Research Centers, Ottawa, Canada.

Lyman, R. A. (1992). Peak and off- Peak Residential Water Demand, Water Resource Research, Vol: 28, No: 9, Page 2159-2167, September 1992, tt

Moore, M. R. (1999). Ability to Pay for Reclamation Water, Land Economics, Volume 75, No: 4November 1999, University of Wisconsin Press.

Nauges, C. Dan Thomas, A. (2000). Privately Operated Water Utilities, Municipal Price Negotiation, and Estimation of Resiedntial Water Demand: The Case of France, Land Economics, Volume 76, No: 1 February 2000, University of Wisconsin Press.

Nelson, A, and Chomitz, K.M.(2004). The Forest-Hydrology_Proverty Nexsus in Central Amerika: An Heuristik Analysis, World bank Policy Research working paper, 3430, tt.

Nieswiadomy, M. L. (1992). Estimating Urban Residential Water Demand:
Dasrizal, Ansofino, Erna Juita, Jolianis Effect of Price Structure, Conservation, and Education, Water Resources Research, Vol 28, No: 3, Page 609-615, Maret 1992, tt.

Nugroho, S. P. (2002). Evaluasi dan Analisis Curah Hujan Sebagai Faktor Penyebab Bencana Banjir di Jakarta, Jurnal Sains \& Tehnologi Modifikasi Cuaca, Vol. 3, No: 2 September 2002, BPPT, Bandung.

OECD (1999). Household Water Pricing; Working Party on Economic and Environmental Policy Integration, OECD, 1999.

Pasandaran, E, et al. ( 1999). Perspektif Keswadayaan Petani Dalam Pengembangan Irigasi Pompa, Prosiding Seminar, PSE and Ford Foundation.

Penning, V. F.W.T, et.all. (2002). Integrated Land and Water Management for Food and Environmental Security, Comprehensif Assesment Research Paper, $\mathrm{tt}$

Pint, E. M. (1999). Household Response to Increased Water Rates During the California Drought, Land Economics, Vol. 75, No: 2 May 1999.

Powell, J. R, Allee, D. J, and Clintock, C. Mc. (1994). Groundwater Protection Benefits and Local Community Planning: Impact of Contingen Valuation Information, American Journal of Agricultural Economic, 76, November 1994, tt.

Provencher, B, dan Burt, O. (1994). A Private Property Rights Regime for the Commons: The Case for Groundwater, American Journal of Agricultural Economic, 76, November 1994, tt.

Puu, T. (1992). Nonlinear Economic Dynamics, Springer Verlag, New York.

Renzetti, S. (1992). Estimating the Stucture of Industrial Water 
Demands: The Case of Canadian Manufacturing, Land Economic, Vol. 68, No: 4, November 1992.

Rosegrant, M.W. ( 1993). Examining the Difference in Self- and Publicly Supplied Firms' Water Demands, Land Economics, Vol. 69, No: 2, May 1993.

Saleth, R. M. (2002). Water Resource and Economic Development; the Management of Water Resource, Edward Elgard Publishing Limited, Massachusets.

Saleth, R. M, dan Dinar, A. (1995). Satisfying Urban Thirst: Water supply Augmentation and Pricing Policy in Hyderabad City, India, World Bank Technical Paper No: 395, World Bank, Washington D.C.

Sarwan, Suharto. Subianto, Tjoek, W. Dan Rodgers, C. (2003). Development of Water Rights in Indonesia, c.rodgers@ cgiar.org. IFRI, Washington .D.C.

Schlager, E. dan Ostrom, E. (1992). Property- Rights Regime and Natural Resources: A Conceptual Analysis, Land Economics, Vol. 68 No: 3 Augustus 1992.

Segerson, K. (1994). The Benefits of Groundwater Protection: Discussion, American Journal of Agricultural Economic, Vol. 76, Desember 1994, tt.

Serageldin, I. (1994). Water Supply Sanitation, and Environmental Sustainability: the Financing Challenge, World Bank, Washington D.C.

Shiva, V. (2002). Water Wars; Privatisasi, Profit, dan Polusi, Insist Press, Yogyakarta.

Showers, K. B. (2002). Water Scarcity and Urban Africa: On Overview of Urban- Rural Water Lingkages, Journal of World Development, Vol. 30, No: 4 Tahun 2002.
Dasrizal, Ansofino, Erna Juita, Jolianis

Simpson, L. dan Ringskog, K. (1997). Water Markets in the Americas, World Bank, Washington D.C. tt

Stephenson, D. dan Petersen, M.S. (1991). Water Resource Development in Developing Countries, Elseveir, Amsterdam.

Stiglitz, J. E. (2002). Globalisasi and Its Discountents, PT Inapublikatama, Jakarta.

Sullivan, C (2002). Calculating a Water Poverty Index, Journal of World Development, Vol. 30, No: 7 Tahun 2002.

Syariman, P ( 1997). Penanggulangan Sedimentasi saluran Induk Tarum Barat Di Wilayah Perum Otorita Jatiluhur, Buletin Pusair No: 24 Tahun VII, Juni 1997. Bandung.

Syaukat, Y. (2000). Dynamic Optimization Methods: Theory and Applications, Mimbar Sosek; Jurnal of Agricultural and Resource socioEconomics, Vol. 13 No: 3 Desember 2000.

The World Bank Water Demand Research Team. (1993). The Demand for Water in Rural Areas: Determinants and Policy Implications, The World Bank Research Observer, Vol. 8, No: 1, January 1993: pp. 47-70.

Thobani, M. (1997). Formal Water Market: Why, When, and How to Introduce Tradable Water Right, The World Bank Research Observer, Vol. 12, No: 2, August 1997: pp 161-179.

Thomas, R.L. (1997). Modern Econometrics: an Introduction, Addison- Wesley, Harlow, England.

Tsur, Y. dan Dinar, A. (1995). Effeciency and Equity Considerations in Pricing and Allocating Irrigation Water, Policy Research Working paper The Work Bank, May 19995.

Van den Berg, J.C.JM. (2002). Handbook of Environmental and Resource Economics, Edward Elgard, 
Northampton Massachussetts, USA.

Verbeek, M, (2000). A Guide to Modern Econometrics, John Wiley \& Son, LTD, New York.

Wakins, D. W dan Mc Kinney, D. C. (1997). Finding Robust Solution to Water Resource Problem, Journal of Water Resources Planning and Management, Vol: 123, N0: 1, January/February, 1997.

Weinberg, M. (2002). Assesing a Policy Grab Bag: Federal Water Policy Reform, American Journal of Agricultural Economic, Vol. 84, No: 3, August, 2002.

Young, R. A. (1996). Measuring Economic Benefits for Water Investments and Policies, IBRD, World Bank, Washington D.C. 